\title{
Parallel Development of Oroqen Folk Music Inheritance and Characteristic Specialty Construction in Colleges and Universities
}

\author{
Xiaofei Sun \\ Academy of Music \\ Heihe University \\ Heihe, China
}

\begin{abstract}
As the intangible cultural heritage, Oroqen folk music has a profound national culture value. Oroqen folk music is an important part of folk music in Heilongjiang. In the evolution of history, this ethnic group has the life style and customs of nomadism, fishing and hunting, which are close to nature. So, their music has the characteristics of lifelikeness, simplicity, affinity and collectivity. We should protect and develop Oroqen folk music. On the basis, school is an important platform to inherit the national culture. Thus, we can inherit and develop the unique knowledge of minorities and carry forward the outstanding culture of ethnic minorities through this platform.
\end{abstract}

\section{Keywords-folk music; Oroqen; inheritance}

\section{INTRODUCTION}

Folk music is an important part of national culture, so the music departments of colleges and universities for nationalities have an inescapable responsibility and obligation to inherit and develop national music culture. Oroqen folk music is an important part of Chinese national music, which is rich in content and various in types. From different angles, it vividly reflects the life and spirit of Oroqen people. However, with the development and progress of the society, the traditional inheritance way of Oroqen folk music suffers a great challenge. It has been unable to meet the need of Oroqen folk music for inheritance. At present, the inheritance of Oroqen folk music in Heilongjiang is gradually weakening. The inheritance way of Oroqen folk music is backward, so it is urgent to find new ways to inherit it. By researching the relationship of national higher education and the national culture, we found that national higher education is an important power to inherit and develop the national culture. The key is to actively develop higher education to solve the shortage of talent problem, and inherit the excellent national music culture. We should specially pay attention to the function of inheriting culture of colleges and universities in ethnic minority areas.

\section{The National Culture Value of Oroqen FolK MUSIC}

As one of China's ethnic minority music, Oroqen folk music has a profound national cultural value. On the one hand, it is an important part of Chinese national music. On the other hand, it is an important part of Chinese national culture. Among 55 ethnic minorities, Oroqen has a low proportion of population. According to the statistics in 1990, the population was 7000. This group has a long history, also known as "E'lechun", "E'luochun" and "E'lunchun". In ancient, it was also called as "Qilin". There are a lot of ideas, which can be traced back to Shiwei. Their language belongs to Tungusic language branch, Manchu - Tungusic language group, Altaic language family. This people has no own character, and they use Chinese characters. During the reign of Emperor Kangxi in Qing Dynasty, people were divided into "Moling Oroqen" (riding Oroqen people) and "Yafahan Oroqen" (walking Oroqen people). Before the founding of the PRC, they were mainly engaged in hunting, and partly engaged in agriculture. After the founding of the PRC, they gradually settled down. Now they are mainly located in Xunke County and Aihui County in Heihe Region, Heilongjiang Province, Huma County and Tahe County in Daxing'anling Region and Jiayin County in Yichun City, Oroqen Autonomous Banner and Buteha Banner in Hulunbeier, Inner Mongolia Autonomous Region. They mainly engage in hunting and agriculture.

The rich and colorful Oroqen folk music has a profound cultural value. There are two important forms of music: one is "Zandaren" (also known as "Jiandawen"), and they are folk songs of Oroqen people; the second is "Lvrigeren", and they are the "three-in-one" of folk songs, folk music and folk dance of Oroqen nationality. The third is "Mosukun". It is a rap art of Oroqen people, which has two performance patterns. One is grief-accent rap, called "Morusukun". The other is joy-accent rap, called "Wulun'enqin" (also known as "Wuqin").

The ideological content of Oroqen folk music is very extensive. For example, "Zandaren" mainly includes description of national social life, praise of labor and lovely home, singing of people's struggle spirit and love story, revealing sufferings in old society, and so on. New folk songs are mainly to sing the happy life and people's longing for a bright future, and to praise the party and the leaders, the great socialist motherland and the four modernizations construction, etc..

Fund Project: Youth Academic Backbone of Heihe University. 
The art form of Oroqen folk music is rich and colorful. For example, "Zandaren" mainly includes songs of hunting, love, grief, children, spirit wine, joy and narration ("Jianzhuen"), dances ("Lvrigeren"), Saman Inviting God Songs and so on. Its artistic characteristics are "with fewer lyrics, long music for voice, free rhythm, resounding tune, and rising and falling melody, pleasant to ears, and rich in vigorous wild flavor".

Thus, the deep national culture value of Oroqen folk music is an indisputable fact.

\section{THE AESTHETIC CHARACTERISTICS OF OROQEN FolK MUSIC}

As a subsystem in Heilongjiang folk art system, Oroqen folk music is an inalienable part of the Northeast folk culture, and is also an important part and basis of Chinese traditional national culture. The musical aesthetic characteristics are mainly expressed in the following aspects:

\section{A. The Aesthetic Characteristic of Affinity}

Affinity is concerned with the relationship between aesthetic subject and aesthetic object. One of the most important features of Oroqen folk rap music is that it is extensively and closed connected with social life, especially the nomadic, fishing and hunting life of the people. Some excellent traditional works go deep into the life of the masses. During festivals and slack season, people talk and sing in room, at the riverside, or perform in the forest. Their contents mainly include history fables, folk tales, heroic epic, family life, and so on. These entertainments become good means to enrich people's life and adjust their spiritual and cultural life. The singing of Oroqen folk music is not like the rap art of Han people which is in theater or teahouse. The performers of Han people sing on stage, keeping a certain distance with audience. The singers of Oroqen people generally site together with audiences and they are integrated into a whole. This "nodistance" performance form is conducive to the exchange of actors and audiences.

Oroqen folk instruments are rare, including "Pennvka" and "Wentuwen". Pennvka is mouth organ which is made of a slender iron bar with two ends close together. A thin steel sheet is sandwiched in the middle with a bend at the point end. When playing, grip it horizontally with left hand, take the thin end in mouth, and play the steel bar with right hand. The quavering steel sheet makes a sound. The melody is simple and deep, the volume is low and the range is narrow within an interval of a fifth. It is a very primitive musical instrument. Young men and women often show their love by playing "Pengnvka". When a young man sees the beloved girl, he will play the mouth organ towards her. If the girl is willing, she will respond with cheerful melody. The excited man will play the mouth organ even more energetically to greet the girl. Then, the girl plays weak and cheerful melody to express her love in a shy way. When people hunt back or become half drunk, they will dance, sing and play Pennvka around a bonfire. They improvise and enjoy themselves to the full.

Therefore, in this sense, "no-distance" is not only reflected in time and space, but also in people's soul and emotion communication.

\section{B. The Aesthetic Characteristic of Simplicity and Life Character}

Simplicity and life character are in terms of aesthetic objects. Oroqen folk rap music, as an aesthetic object, is unlike the professional music with careful and rigorous conception and complex performance means. It has two aesthetic features, simplicity and life character.

Simplicity is mainly showed in succinct technique of expression. Most Oroqen folk music works have clear ideological content. Generally they don't divorce from the specific content, or from thoughts and feelings of the characters. They have no pure technique of decoration. So, the images of characters are sincere and moving, give people "a fantasy feeling of real life", and thus show the original appearance of real life in a beautiful way.

Oroqen folk songs have no fixed musical tunes, and have rich changes. The same musical tune is played differently in different regions. It mainly has five-tone scale, as well as sixtone scale and seven-tone scale. It mainly uses Yudiao tune, and Gongdiao tune as supplementary, less Shangdiao tune. It mainly uses $3 / 8$ beat or $6 / 8$ beat, as well as $24 /$ beat and 34/ beat. The tune structure is generally in strophic form of single musical period. Some are in repeat singing of a short name. It uses portamento and vibrato quite a lot, so that the song can go out very far and has a strong shock.

The life feature is mainly showed in the close combination with the ethnic language. The singing of music is always combined with the language of the ethnic group. For example, in chanting "Wuqin", singers exaggerate the high and low tone, short and long sound, weak and strong point of libretto, so that it has the characteristics of "singing seeming to be non-singing and speaking seeming to be non-speaking". When Oroqen people sing songs, they improvise or hum a fixed melody. If they improvise, they sing what they see or think. There is no lyric. The place for singing "Wuqin" is not fixed. They can be on kang bed, in the forest or at the riverside. The time is also not fixed. The songs often are related to life and nature environment, so they can reflect the local flavor. It is a perfect integration of life, natural environment and folk customs. Oroqen folk art is also combined with their own folk customs. On wedding or holidays, there will be the performance of folk rap. On the wedding, a responsorial singing game will be played between the bride's side and the groom's side. If the bride's side is defeated, the bride is hard to go to the bridal chamber. Therefore, the two sides will select singers with sharp language and quick response to participate in the game.

The spontaneity of aesthetic activities makes Oroqen folk music closer to life and the objective law of real beauty, which convinces the audiences. It contains a real feeling, and it is the real feeling that moves the audiences. So, they can enter into the palace of aesthetic art.

\section{THE NATIONAL MUSIC INHERITANCE AND CHARACTERISTIC MuSIC SPECIALTY CONSTRUCTION IN COLLEGES AND UNIVERSITIES}

The inheritance of national music culture has a positive interactive relationship with the setting of characteristic music 
specialty in colleges and universities. The teaching-style local colleges and universities mainly take applied education as priority. They can introduce folk music into class according to social needs and region advantage and other advantages, reform the talent training mode and curriculum system of music education, and thus endow it with local ethnic characteristics. Only by developing their own characteristics, can their music education have vitality and attractiveness. It is not only reflected in the establishment of the target, but also in educators, education objects, teaching resources, teaching process, teaching results and other aspects. It is a systematic project.

\section{A. To Stimulate Students' Interest in Learning}

First of all, colleges and universities with folk music education as characteristic specialty should incline to the minority candidates and the candidates interested in folk music learning in enrollment. They should first inspire students' sense of identity, and help students become interested in folk music and gain music experience in teaching. And then they should value the impact of environment, encourage students to participate in social practice and implement open education. They can integrate folk music into music education through the process of "listening appreciation, experience and interest" to stimulate students enthusiasm for learning and let students do what they want to do through these measures. Thus, they can instill national music knowledge and strive to improve students' national music quality, and achieve the purpose of teaching.

\section{B. Music Teaching Material Is the Carrier and Guarantee of Music Education}

It is the most important resource in music teaching. At present, the folk music teaching resources is imbalanced. There are a few music materials of marginal ethnic groups. Some instrumental materials are difficult to find. The selection of music materials should stick to the principle of highlighting folk music education characteristics and reflecting characteristic folk music view. It is not necessarily confined to the publishing departments. We can also invite experts and scholars and folk music performers to assist in the preparation of teaching materials. We should discard the dross and select the essential in selecting professional materials, keep a foothold in material mining, collect and sort folk materials and local teaching material, and extract essence. We can also use the field investigation method to let teachers and students go to the people, find and excavate ranges through collecting folk songs, research and interview, so that the folk music resources scattered in the folk can be collected as new teaching materials. Students may understand that folk music is the source of all music creation through these activities, adore national music psychologically, and deepen their love on the national music.

\section{Music Education Courses in Colleges and Universities Are Basically Modeled on Professional Art Institutions}

The curriculum is based on the study of western music theory, western music and national music. Most teachers have no systematic study of the relevant knowledge and skills of national music, which, to a certain extent, restricts the overall development of national music education. So, the first task is to improve teachers' quality and teaching ability. Teachers can improve themselves through teaching practice and equip themselves with three accomplishments, basic music accomplishment, national music accomplishment and national music teaching accomplishment. If some schools cannot develop national music education due to causes of teachers, they can employ external professional teachers. If some schools determine to develop national characteristic education, they can provide teachers with professional training. If necessary, they can send teachers to professional music institutions, local cultural arts groups and non-governmental educational institutions to study, in order to adapt to the teaching needs.

Colleges and universities should continue to improve their subject construction, and undertake the historical mission of inheriting folk music culture in curriculum setting and teachers' growth in order to achieve characteristic education. They can share out the work and cooperate with one another in the process of inhering folk music culture, constantly adapt to the era development to meet the actual demand of society for music talent, and assume the historical mission of inheriting the minority folk music culture.

\section{REFERENCES}

[1] Li Anbang, Fang Ming. Significance of Education for Cultural Innovation. Shanghai Education and Scientific Research, 1998.

[2] Dong Weisong. Chinese Traditional Music and Its Classification. Chinese Music, 1987 (2).

[3] Xiang Daxun. Patriotic Musician Zhao Meibo Carrying Forward National Music. Chinese Music Culture Education. No. 96.

[4] Wang Yaohua. Significance and Outlook of Music Education. Music Research, 1996 (2). 